\title{
Constraints Faced in Adoption of Establishment Techniques of Wheat in Karnal and Kaithal Districts of Haryana
}

\author{
Ajay Singh, Dalip Kumar Bishnoi, Nirmal Kumar and Raj Kumar* \\ Department of Agricultural Economics, CCSHAU, Hisar, Haryana, India \\ *Corresponding author: rajkumarkashyap301@gmail.com (ORCID ID: 0000-0003-3089-6234 )
}

Received: 23-12-2019

Revised: $17-04-2020$

Accepted: $25-05-2020$

\begin{abstract}
The study was conducted in Karnal and Kaithal districts of Haryana in 2017-18. Total forty (40) farmers were selected randomly from Karnal and Kaithal districts of Haryana. The major constraint in the study area for conventional technique of Karnal were problem of weed infestation, less effective Weedicides, non adoption of seed treatment, non adoption of recommended doses of fertilizers and high cost of potashic fertilizers. Same problems were observed under conventional technique in Kaithal district with slight more in percentage. Major problems of zero tillage technique in Karnal district includes problem of poor effective Weedicides, weed infestation, problem of less germination, limited availability of zero tillage machine at the time of sowing, non adoption of seed treatment and high cost of potashic fertilizers. Same problem were noticed under zero tillage technique in Kaithal district with slightly more in percentage. Major problems of turbo happy seeder technique noted in Karnal district were the problem of less effective Weedicides, weed infestation, limited availability of zero tillage machine at the time of sowing, high cost of potashic fertilizers, non adoption of seed treatment and problem of poor germination. Identical problems were observed under turbo happy seeder technique in Kaithal district with slightly more percentage.

\section{Highlights}

( Weed infestation, less effective Weedicides, non-adoption of recommended doses of fertilizers, high cost of potashic fertilizers and limited availability of zero tillage machine at the time of sowing were found as the major constraints confronted in adoption of establishment techniques of wheat by the farmers in the study area.
\end{abstract}

Keywords: Infestation, weed, shortage, machine, problems

Wheat (Triticum aestivum L.) is a crop of universal importance. In World, total area under wheat cultivation was 225 million hectares and production 761.3 million tonnes in 2016. India ranks second position in wheat production all over the world with area 30.78 million hectares and production 98.51 million tonnes in year 2016 with a productivity of $3200 \mathrm{~kg} / \mathrm{ha}$. Main wheat producing states in India are Uttar Pradesh, Madhya Pradesh, Punjab, Haryana and Rajasthan. Haryana was important wheat producing state in the country with area and production 2.55 million hectares and 11.54 million tonnes in 2016 respectively. The productivity of wheat in Haryana was $4514 \mathrm{~kg} / \mathrm{ha}$. (DAC\&FW,
2016). There were few extension constraints like lack of adequate manpower with the state department of agriculture and input agencies. The farmers also mentioned lack of money to purchase new machines and inputs. Lack of appropriate loose straw management, high cost of tillage, lack of money to buy machines and inputs, inadequate extension facilities were the serious constraints perceived by the non adopters. The new challenges demand

\footnotetext{
How to cite this article: Singh, A., Bishnoi, D.K., Kumar, N. and Kumar, R. (2020). Constraints faced in adoption of establishment techniques of wheat in Karnal and Kaithal districts of Haryana. Economic Affairs, 65(2): 179-181.

Source of Support: None; Conflict of Interest: None
} 
economical use of resource and conservation to satisfy the rising needs. Troubles with conservation have assumed importance in view of widespread resource degradation problems and the need to reduce production cost, increase profitability and make agriculture more competitive. To attain the target of sustainable agriculture, scientists are now more serious than ever before. Conservation Agriculture (CA) has been recognized as the immediate as well as long-term solution to achieve goals of sustaining productivity, economic natural resource based and growth of the Indian farme Rs. The term CA refers to the system of raising crops without tilling the soil while retaining crop residues on the soil surface. The key elements which characterize CA includes minimum soil disturbance by adopting no-tillage and least amount traffic for agricultural operations, leaving and managing the crop residues on the soil surface, and adopting spatial and temporal crop sequencing/crop rotations to derive maximum benefits from inputs and minimize adverse environmental impacts (Abrol and Sangar 2006).

\section{MATERIALS AND METHODS}

A list of all the important constraints affecting the production was prepared with help of wheat growers. Regarding constraints analysis, the response (various constraints as perceived by the farmers in production of wheat through conventional, zero tillage and turbo happy seeder techniques in wheat.) were recorded on three point continuum i.e. very serious, serious and some what serious and subsequently assigned a weight-age of 3, 2 and 1, respectively. The constraints score of each respondent as well as of all the respondents for each item pertaining to production constraints in conventional, zero tillage and turbo happy seeder techniques was worked out. The mean score and rank order were also computed.

Following formula was employed to calculate Mean Percent Score:

Mean Score $=\frac{\text { Sum of score }(\text { constraint }) \text { for all responses }}{\text { Total number of respondents }}$

Mean Percent Score $=$

$$
\frac{\text { Mean of item (constraint) for all responses }}{\text { Maximum score of the item (constraint) }} \times 100
$$

\section{RESULTS AND DISCUSSION}

Table 1: Production constraints in conventional technique (CT) in Karnal and Kaithal districts of Haryana $(\mathrm{N}=40)$

\begin{tabular}{llccc}
\hline $\begin{array}{l}\text { S1. } \\
\text { No. }\end{array}$ & Constraints / Problems & MS & MPS & $\begin{array}{c}\text { Rank } \\
\text { order }\end{array}$ \\
\hline 1 & Weed infestation problem & 2.1 & 70.00 & 1 \\
2 & $\begin{array}{l}\text { Less effective Weedicides } \\
\text { Non adoption of seed }\end{array}$ & 1.5 & 50.00 & 2 \\
3 & 0.9 & 30.00 & 3 \\
& $\begin{array}{l}\text { treatment } \\
\text { Non adoption of } \\
\text { recommended doses of } \\
\text { fertilizers }\end{array}$ & 0.55 & 18.33 & 4 \\
5 & $\begin{array}{l}\text { High cost of potashic } \\
\text { fertilizers }\end{array}$ & 0.5 & 16.67 & 5 \\
\hline
\end{tabular}

Table 2: Production constraints in zero tillage technique (ZTT) in Karnal and Kaithal districts of Haryana $(\mathrm{N}=40)$

\begin{tabular}{llccc}
\hline $\begin{array}{l}\text { S1. } \\
\text { No. }\end{array}$ & Constraints / Problems & MS & MPS & $\begin{array}{c}\text { Rank } \\
\text { order }\end{array}$ \\
\hline 1 & Less effective Weedicides & 1.50 & 50.00 & 1 \\
2 & Weed infestation problem & 1.20 & 40.00 & 2 \\
3 & $\begin{array}{l}\text { Problem of less germination } \\
\text { Limited availability of zero }\end{array}$ & 0.85 & 28.33 & 3 \\
4 & $\begin{array}{l}\text { tillage machine at the time of } \\
\text { sowing }\end{array}$ & 0.60 & 20.00 & 4 \\
5 & $\begin{array}{l}\text { Non adoption of seed } \\
\text { treatment }\end{array}$ & 0.60 & 20.00 & 4 \\
6 & High cost of potashic fertilizer & 0.55 & 18.33 & 6 \\
\hline
\end{tabular}

Table 3: Production constraints in turbo happy seeder technique (THST) in Karnal and Kaithal districts of Haryana $(\mathrm{N}=40)$

\begin{tabular}{|c|c|c|c|c|}
\hline $\begin{array}{l}\text { Sl. } \\
\text { No. }\end{array}$ & Problems & MS & MPS & $\begin{array}{l}\text { Rank } \\
\text { order }\end{array}$ \\
\hline 1 & Less effective Weedicides & 1.00 & 33.33 & 1 \\
\hline 2 & Weed infestation problem & 0.85 & 28.33 & 2 \\
\hline 3 & $\begin{array}{l}\text { Limited availability of turbo } \\
\text { happy seeder at the time of } \\
\text { sowing }\end{array}$ & 0.60 & 20.00 & 3 \\
\hline 4 & $\begin{array}{l}\text { High cost of potashic } \\
\text { fertilizers }\end{array}$ & 0.55 & 18.33 & 4 \\
\hline 5 & $\begin{array}{l}\text { Non adoption of seed } \\
\text { treatment }\end{array}$ & 0.45 & 15.00 & 5 \\
\hline 6 & $\begin{array}{l}\text { Non adoption of } \\
\text { recommended doses of } \\
\text { fertilizer }\end{array}$ & 0.45 & 15.00 & 5 \\
\hline 7 & Problem of less germination & 0.45 & 15.00 & 5 \\
\hline
\end{tabular}


The results of the study revealed that problem of weed infestation, less effective Weedicides, non adoption of seed treatment, non adoption of recommended doses of fertilizers and high cost of potashic fertilizers as major constraints which were inhibiting the production as well as profitability of conventional technique of wheat in both Karnal and Kaithal districts of Haryana. It was similar with the finding of (Bhatia and Dhaliwal, 2001), (Kumar et al. 2007) and (Ahmed and Sulaiman, 2011) in their respective studies. Similarly, in case of zero tillage technique (ZTT), problem of less effective Weedicides, weed infestation, poor germination, limited availability of zero tillage machine at the time of sowing, high cost of potashic fertilizers and non adoption of seed treatment were observed some of the major constraints those effecting the adoption as well as profitability of zero tillage technique in Karnal as well as Kaithal districts of Haryana. It was in conformity with the finding of (Dhaliwal and Singh, 2005), (Kumar et al. 2010) and (Tripathi et al. 2013) While, in case of turbo happy seeder technique (THST), problem of less effective Weedicides, weed infestation, limited availability of turbo happy seeder at the time of sowing, high cost of potashic fertilizers, non adoption of seed treatment, and problem of poor germination were observed some of the major constraints those effecting the adoption as well as profitability of turbo happy seeder technique in Karnal as well as Kaithal districts of Haryana. Although these constraints were found less in per-cent as compared to (ZTT) and (THST). It was similar with the finding of (Ramakrishna et al. 2005), (Singh and Dhaliwal, 2008), (Sidhu et al. 2015) and (Yogi et al. 2015) in their respective studies.

\section{CONCLUSION}

Weed infestation problem was found common in all the three establishment techniques of wheat. However the infestation was more in conventional technique as compare to zero tillage and turbo happy seeder technique. Seed treatment knowledge was found less in the farmers doing conventional tillage as compared to the farmers using zero and turbo happy seeder techniques. Problem of poor germination was found more in zero tillage technique as compared to turbo happy seeder and conventional technique. Availability of zero tillage and turbo happy seeder machines was found to be insufficient during the peak time of sowing. No technical constraints were viewed seriously by the farmers in the adopter category, however, there were few extension constraints like lack of adequate manpower with the state department of agriculture and input agencies. The farmers also mentioned lack of money to purchase new machines and inputs. Lack of appropriate loose straw management, high cost of tillage, lack of money to buy machines and inputs, inadequate extension facilities were the serious constraints perceived by the non adopters.

\section{REFERENCES}

Ahmed, E., Sulaiman, J. and Mohd., S. 2011. Wheat production and economics. American Journal of Agricultural and Biological Sciences, 6(3): 332-338.

Bhatia, B.S. and Dhaliwal, I.S. 2001. Strip tillage: for sowing wheat without tillage. Conserv Agric-Status and Prospects PAU, Ludhiana, 40(4): 280-290.

Dhaliwal, H.S. and Singh, J. 2005. Socio-economic impact of zero-tillage technology in wheat in Punjab. Conserv. Agric-Status and Prospects, 26(7): 67-78

Kumar, A., Prasad, K.., Kushwaha, R.R., Rajput, M.M and Sachan, B.S. 2010. Determinants Influencing the Acceptance of Resource Conservation Technology: Case of Zero-Tillage in Rice- Wheat Farming Systems in Uttar Pradesh, Bihar and Haryana States. Indian Journal of Agriculture Economics, 65(3): 448-460.

Kumar, A., Singh, R. and Shoran, J. 2007. Constraints analysis of wheat cultivation in eastern India. Indian. Journal of Agriculture, 41(2): 97-101.

Ramakrishna, Y.S., Vittal, K.P.R. and Sharma, K.L. 2005. Conservation agriculture in rain fed semi arid tropics. Some past experiences, lessons learnt and future scopes. Conserv. Agriculture-Status Prospects, 10(3): 55-69.

Sidhu, H.S., Singh, M., Singh, Y., Blackwell, J., Lohan, S.K., Humphreys, E., Singh, V. and Singh, S. 2015. Development and evaluation of the turbo happy seeder for sowing wheat in to heavy rice residues in NW India. Field Crops Research, 10(1): 1-12.

Singh, R.P., Dhaliwal, H.S., Humphreys, E., Sidhu, H.S. and John Blackwell. 2008. Economic assessment of the Happy Seeder for rice-wheat systems in Punjab, India. Indian Journal of Agriculture Research, 11(4): 1-30.

Singh, R., Kumar, A. and Chand, R. 2007. Accelerating Adoption of Zero Tillage Technology. Indian Research Journal of Extension Education, 7(1): 6-10.

Triphathi, R.S., Raju, R. and Thimmappa, K. 2013. Impact of zero tillage on economics of wheat production in Haryana. Agricultural Economics Research Review, 26(1): 101-108.

Yogi, V., Kar, A., Bhardwaj, S. and Mehla 2015. Impact of zero tillage practices on economics of wheat cultivation in Haryana. International Research Journal of Agricultural Economics and Statistics, 6(2): 376-381. 
